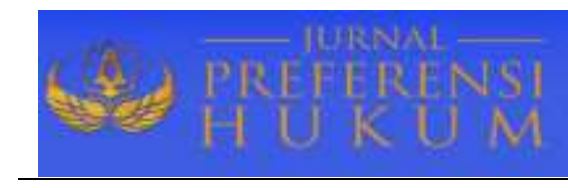

Jurnal Preferensi Hukum | ISSN: 2746-5039

Vol. 2, No. 2 - Juli 2021, Hal. 238-242| Available online at https://www.ejournal.warmadewa.ac.id/index.php/juprehum

DOI: https://doi.org/ 10.22225/jph.2.2.3315.238-242

\title{
PERLINDUNGAN HUKUM TERHADAP PENGGUNA JASA TELEKOMUNIKASI DALAM PELANGGARAN DATA PRIBADI MELALUI SMS BROADCAST
}

\author{
Aziiz Muhaimin, Ni Made Jaya Senastri, Ni Made Sukaryati Karma \\ Fakultas Hukum Universitas Warmadewa, Denpasar-Bali, Indonesia \\ azisslub@gmail.com, nimadejayasenastri@gmail.com, madesukaryatikarma@gmail.com
}

\begin{abstract}
Abstrak
Kemajuan era modern saat sangat memudahkan akses terutam dalam interaksi, dengan hadirnya teknologi internet, SMS dan media sosial menjadi media utama masyarakat dalam bersosialisasi dan melakukan promosi dengan biaya yang terjangkau serta cepat dalam menjangkau konsumen, sehingga secara tidak langsung terjadinya pertukaran informasi data pribadi yang tidak diketahui oleh pengguna jasa yang seringkali disalahgunakan oleh orang yang tidak bertanggung jawab, dalam praktiknya yaitu menggunakan SMS Broadcast dimana merupakan salah satu metode pengiriman pesan ke banyak nomor dari satu sumber dengan pesan yang sama dengan satu nomor ke nomor konsumen yang lain. Penelitian ini mengkaji pengaturan hukum bagi pengguna jasa telekomunikasi bidang periklanan dan menganalisisi perlindungan hukum bagi konsumen dengan adanya pelanggaran data pribadi melalui SMS Broadcast. Adapun metode yang akan digunakan yaitu penelitian hukum normatif, dengan pendekatan konsep dan Perundang-undangan. Sumber data yang digunakan adalah bahan hukum primer, sekunder dan tersier yang dikumpukan dengan cara cara mencatat, mengutip, membaca, maupun meringkas literatur yang mengacu terhadap perubahan status jenis kelamin di Indonesia. Selanjutnya data dianalisis dengan sistematis dan mengaitkannya dengan bahan hukum. Hasil simpulan ini menguraikan bahwa dimana Pasal 1 Undang-Undang Perlindungan Konsumen dijadikan dasar hukum perlindungan terhadap pengguna jasa telekomunikasi, sedangkan pada Pasal 26 UU ITE dijadikan dasar hukum tentang penggunaan data pribadi, yang dalam hal ini adalah SMS Broadcast.
\end{abstract}

Kata kunci: Data Pribadi, Perlindungan Hukum, SMS Broadcast

\begin{abstract}
111 the progress of the modern era today where the development of internet technology,SMS and social media becomethe main thing in every need of society in socializing and conductingpromotionsat an affordablecost andfast in reaching consumers, so that indirectlythe exchange ofpersonaldata informationthat is not known by service users who are often misused by irresponsiblepeople. Which in practiceis to use SMSBroadcast which is one method of sending messagesto many numbers from one source with the same message with one number to another consumer number. From the statement, there are 2 problems, namely How to set the law of telecommunicationservice users in the field of advertising and How to protectthe lawfor consumers with the existence ofpersonaldata breaches through SMS Broadcast.The method to be used is a method of normative legal research. The conclusion outlines that Article I of the Consumer Protection Law Serves as the legal basis for the protection of telecommunication service users, while in Article 26 of the /TE Law is used as the legal basis for the use of personal data, which in this case is SMS Broadcast
\end{abstract}

Keywords: Legal Protection,SMS Broadcast,PersonalData

\section{PENDAHULUAN}

Perkembangan dari teknologi informasi saat ini telah memberikan dampak yang begitu besar bagi manusia. Jaman ini terkenal dengan era teknologi informasi. Salah satunya yaitu dapat mencari informasi, Alat komunikasi yang dapat ditemukan pada masyarakat unruk dapat mengakses beberapa informasi adalah telepon seluler. Dari media elektronik seperti telepon seluler tersebut masyarakat bisa mengetahui beberapa madengan cepat menggunakan alat-alat teknologi yang begitu canggih sehingga mudah mendapatkan serta berbagi informasi tanpa mengenal waktu dan jarak. Globalisasi produksi beberapa sektor yaitu keuangan, teknologi dan perdagangan terbentuklah market atau pasar yang terbentuk. Perkembangan dari kemajuan teknologi telekomunikasi dan informatika memperbesar arus transaksi barang dan jasa yang diberikan bervariasi antara lain produksi luar negeri dan dalam negeri. lnformasi elektronik mengenai barang dan jasa dikatakan para pengusaha itu tidak hanya memperlihatkan kelebihan yang ada pada beberapa produk, tetapi harus dengan memuat informasi dari risiko pemakaian yang terdapat dari produk bersangkutan, terlebih menyangkut dengan hak dari 
konsumen, sehingga konsumen dapat menggunakan informasi tersebut yang diberikan oleh pengusaha untuk memilih produk yang baik (Sidabalok, 2006). Namun dalam hal ini diketahui, tindakan-tindakan yang dilakukan oleh pihak pelaku usaha mengirimkan berbagai promosi baik dalam bentuk barang atau jasa melalui SMS ke banyak nomor seluler untuk lebih menarik minat pembeli/konsumen yang disebut SMS Broadcast. SMS Broadcast adalah metode mengirim pesan ke beberapa nomor dari saru nomor dengan isi pesan yang sama tapi memakai data pengirim yang tidak terkirim dari nomor seluler biasa. SMS Broadcast juga sering dianggap sebagai SMS Iklan karena dianggap mengganggu pengguna seluler yang menerima pesan tersebut. hal ini dapat dilakukan pembahasan mengenai pengaturan hukum pengguna jasa telekomunikasi dalam bidang periklanan tersebut. Dan perlindungan hukum bagi konsumen dengan pelanggaran data pribadi melalui SMS Broadcast dapat dilihat dari sudut pandang hukum. SMS broadcast yang dikirim oleh penyedia jasa layanan operator seluler kepada pengguna jasa layanan operator seluler tidak sesuai dengan aturan yang berlaku sehingga pesan tersebut dianggap Spam, hal ini menimbulkan kerugian pengguna jasa tersebut (Helmi, 2011).

Perusahaan penyedia jasa layanan operator seluler wajib bertanggung gugat atas kerugian yang diderita konsumen akibat kelalaian yang dilakukan. Pihak pelaku usaha telah melanggar kewajiban yang seharusnya ditaati oleh setiap pelaku usaha dalam menjalankan kegiatan usahanya. Dalam hal ini, pengguna jasa layanan operator seluler yang dilanggar hak-haknya dapat mengajukan gugatan berdasarkan perbuatan melanggar hukum kepada pelaku usaha melalui jalur litigasi (melalui lembaga peradilan). Periklanan pada umumnya adalah proses yang menjangkau penyiapanMedia yang biasanya dipakai saat memberikan pengiklanan adalah melalui tv, surat kabar, serta surat yang langsung diberikan kepada konsumen.

SMS Broadcast dipergunakan untuk melakukan promosi secara efektif dan efisien dengan biaya yang murah dan hanya dalam waktu yang singkat. Perusahaan yang menawarkan barang atau jasa tersebut merasa sangat diuntungkan dengan adanya SMS Broadcast. Tetapi bagi beberapa pengguna jasa telekomunikasi atau konsumen yang menerima berbagai pesan promosi melalui SMS Broadcast merasa bahwa privasinya telah terganggu dan dirugikan dengan adanya promosi yang dilakukan melalui SMS Broadcast tersebut karena dapat menimbulkan SMS secara bersamaan dalam waktu yang singkat (Dewi, 2016). Dari uraian di atas , maka penelitian ini mengkaji pengaturan hukum bagi pengguna jasa telekomunikasi bidang periklanan dan menganalisisi perlindungan hukum bagi konsumen dengan adanya pelanggaran data pribadi melalui SMS Broadcast.

\section{METODE PENELITIAN}

Penelitian ini menggunakan penelitian hukum secara normatif, dimana mengacu kepada studi kepustakaan di bidang hukum, dengan menggunakan pendekatan masalah secara konseptual dan pendekatan kasus. Bahan hukum yaitu hukum primer yaitu bahan hukum yang berpedoman terhadap Undang-undang dan keputusan yang mengikat, bahan hukum sekunder diperoleh dimana didapat melalui jumal, buku hukum, serta internet yang memuat mengenai kasus SMS iklan di sosial media, sedangkan bahan hukum tersier diperoleh melalui kamus hukum serta ensiklopedia yang berkaitan mengenai informasi hukum (Bambang, 2002). Data dikumpulkan dengan cara mencatat, mengutip, membaca, maupun meringkas literatur yang yang berkaitan dengna masaah yang diteliti. Selanjutnya bahan hukum di analisis dengan sistematis dan mengaitkannya dengan bahan hukum.

\section{HASIL DAN PEMBAHASAN}

\section{Pengaturan Hukum Pengguna Jasa Telekomunikasi dalam Bidang Periklanan}

Sampai saat ini tidak ada peraturan serta perundangan maupunn Undang-undang baik itu mengatur dengan khusus mengenai periklanan. Dasar dari peraturan mengenai periklanan dimuat pada perundangan Undang-undang lnformasi dan Teknologi dan Undang-undang hukum dagang. Dalam penjelesan tentang data pribadi unruk menjamin perlindungan data tersebut disebutkan pada pasal 26 UU ITE mengenai hak pribadi dalam melakukan komunikasi dan tanpa adanya gangguan yang terjadi. Mengenai masalah tentang periklanan terdapat dimasukan pada asas-asas seperti asas-asas umum tata krama serta tata cara pada periklanan di Indonesia, dalam hal tersebut dijelaskan bahwa pada iklan tentunya harus memiliki sebuah kejujuran serta memiliki tanggung dan tentunya tidak bertentangan pada hukum yang sudah berlaku di Indonesia serta tidak mengandung maksud rasis ada menyerang golongan tertentu seperti halnya seperti agama dan golongan tertentu lainnya. 
Dalam hal tata krama serta tata cara periklanan di Indonesia memiliki pengaturan tentang kaitan pada unsur-unsur yang bersangkutan pada periklanan, baik secara hubungan pada konsumen, pengiklanan pribadi, pemerintah serta media. Hubungan pada konsumen jika diinginkan oleh konsumen, maka dari itu baik pada perusahaan periklanan, maupun halnya pada media pengiklan tetap harus bersedia memberi pengertian tentang iklan tertentu. Hal tersebut secara kaitannya dengan adanya hak-hak konsumen, oleh sebaba itu masalah periklanan dimana diatur pada pasal 8 sampai dengan pasal 16 baik itu secara khusus dengan pasal 17 UUPK, sebagaimana mengatur perbuatan-perbuatan larangan pada pelaku usaha. Secara serta merta pada pasal 17 VUPK menerangkan larangan bahwa mengelabui konsumen tentang kualitas dan lainnya sebagainya serta tidak memberikan informasi apalagi memberikan informasi yang keliru atau melanggar etika serta pengaturan perundang-perundangan. Larangan serta berupa sanksi diatur pada pasal 62 UVPK bahwasannya pada pelaku usaha periklanan yang rnelakukan pelanggaran pasal 17 ayat I dapat dijabarkan bahwa orang yang melanggar dapat dikenai sanksi berupa dipidana paling lama yaitu lima tahun serta dapat dipidana denda sebesar dua milyar rupiah. Sedangkan dalam pelanggaran yang dilakukan oleh pelaku usaha periklanan diberikan pidana paling lama selama dua tahun serta paling banyak rnendapatkan denda sebesar lima ratus milyar rupiah (Miru, 2011).

Tanggung jawab tentunya dimiliki oleh pelaku usaha sesuai Undang-undang No.8 Tahun 1999 tentang Perlindungan konsumen pada dasarnya memiliki prinsip contractual liability. Pada pasal 18 UUPK menjelaskan serta mengatur bahwasannya dalam memberikan penawaran barang ataupun jasa yang diberikan untuk diperjual belikan, serta pelaku usaha ini dilarang memakai klausula yang baku saat setiap dokumen ataupun perjanjian pada (Johanes, 1999). Pada ketentuannya dalam UUPK sebagaimana diatur tentang product liability ini yaitu pasal 19 UUPK, bahwa sebagaimana pelaku usaha yang bertanggung jawab memberi ganti rugi pada kerusakan yang diakibatkan saat mengkonsumsi barang saat dihasilkan serta perdagangkan. Kerusakan yang terjadi dikarenakan oleh pelaku usaha tentunya melanggar larangan seperti yang dicantumkan pada pasal 8 sampai pada pasal 17 VUPK.

Mengenai perkembangan menggunakan SMS Broadcast khususnya Indonesia banyak pengguna di Indonesia, bahkan negara lain seperti Eropa tentunya lebih populer tetapi di Amerika Serikat pelayanan ini sangat jarang dipakai. Pada dasarnya SMS ini sangat popular dikarenakan relatif murah. Akan tetapi perkembangan SMS banyak ditanggapi sebagai media yang negatif, seperti contohnya provider Telkomsel banyak mengeluhkan yang disebabkan oleh penjagaan privasi dari setiap penggunannya. Hal itu terjadi karena banyak pelanggan yang mendapatkan SMS dari nomor tidak dikenal dan promosi yang sering dikirimkan setiap 2 minggu sekali. Sehinga menyebabkan terjadinya SMS Spam atau Spamming. Permasalahan yang terjadi ini adalah bahwa pelanggan atau pengguna telkomsel ini tidak ingin mendapatkan pesan yang sama sekali tidak ada sangkut pautnya terhadap kebutuhannya. Orang yang mendapatkan SMS belum tentu menerima atau mengizinkan operator untuk mengirim pesan tersebut. Dari kasus tersebut dimana selain pengusaha yang dapat mengirimkan pesan tersebut perusahaan yang terdaftar juga dapat mengirim pesan tersebut, perusahaan yang dimaksud terkandung dalam KUHD pada pasal 16 buku bagian 2, tidak sama dengan pengusaha rintisan dimana hubungan antara pengguna jasa telekornunikasi tersebut tidak merniliki ikatan secara khusus. Karena perusahaan hanya bekerjasama dengan provider.

Berdasarkan hal tersebut, maka menteri komunikasi dan infonnasi melakukan pembatasan yang dituangkan dalam peraturan menteri No.1/PER/M.KOMINF0/0I/2009 tentang penyelenggaraan pesan singkat ke banyak nomor yang pembatasannya disebut pada Pasal 18. Sehingga nantinya pengguna jasa telekomunikasi dapat menolak atau menerima pesan sms iklan tersebut sesuai yang diinginkan oleh konsumen. Promosi dalam hal ini merupakan kegiatan yang saling memberikan komunikasi antara produk dan konsumen. Bentuk promosi yaitu merupakan hasil kegiatan pada perusahaan saat saling komunikasi. Media yang biasanya digunakan adalah tv, radio dan majalah ataupun surat yang dimana langsung dikirimkan kepada calon konsumen.

Penjualan pribadi adalah merupakan proses yang dimana pelanggan diberikan info. Tujuan dari hal ini adalah untuk mempromosikan suatu produk pada calon pembeli yang akhirnya mencoba untuk membeli. Promosi penjualan merupakan persuasif secara langsung melewati penggunaan intensif yang dimana dapat merangsang pembelian (Winardi, 1992). Pemasaran langsung merupakan sebuah proses sistem dari marketing organisasi berkomunikasi baik secara langsung pada target. Hal ini dilakukan untuk membuat tujuan untuk mendapat respon dari pelanggan. Sedangkan relasi publik yang dimaksud adalah untuk menaikan citra produk untuk menjadikan citra yang baik. 


\section{Perlindungan Hukum Bagi Konsumen dengan Adanya Pelanggaran Data Pribadi Melalui Sms Broaocast}

Adanya hubungan antar orang yang satu dengan pihak yang lain yang kemudian muncul suatu masalah hukum. Hak akan selalu ada dalam kewenangan di dalam diri seseorang untuk melakukan sesuatu yang kemudian akan menjadi suatu objek dari hak tersebut kepada orang di sekitar. Selain adanya hak harus juga terdapat kewajiban yang mana diketahui kewajiban adalah perilaku orang untuk mendapatkan haknya pribadi dalam hubungan terkait hukum. Objek hukum merupakan hal yang sangat amat pentingnya, yang memiliki nilai tinggi yang nantinya akan bisa digunakan sebagai pokok dasar suatu hubungan hukum. Dimana dasarnya subyek hukum bisa dikatakan sesuatu yang utama yang menjadi kewajiban dan hak atau suatu kewenangan dari hukum. Hubungan antara konsumen dan pihak produsen akan ada suatu ikatan yang berkaitan dengan suatu jasa dan ataupun suatu barang yang muncul dari adanya teknologi. Soal tentang perlindungan konsumen sangat penting di erat teknologi ini. Bisa kita lihat perkembangan di industri dan teknologi yang mana memungkinkan sekali masyarakat ikut hadirdan terlibat dengan masalah perlindungan konsumen. Adanya timbul gugatan yang dimana hanya akan dapat ditujukan kepada pihak yang ada sangkutannya dengan hukum. Oleh karenanya timbul suatu gugatan konsumen akan timbul pihak yang kemudian pasti akan digugat. Jika dilihat dalam pengertian arti sebuah konsumen ada suatu hubungan antara pengguna jasa SMS Broadcast dan pelaku dari suatu penyedia suatu jasa dimana dilakukan hubungan suatu tindakan konsumen dimana bertujuan melakukan transaksi bisnis maupun ekonomi dengan pelaku di dalam bagi pengguna jasa SMS Broadcast. Transaksi tersebut adalah suatu wujud dari adanya suatu sepakat dari pihak-pihak yang membuat adanya kewajiban diantara masing-masing pihak (Kristiyanti, 2011). Hubungan suatu hukum hanya akan dapat terjadi antara subyek benda dan subyek hukum. Hubungan dari keduanya dapat timbul antara badan hukum dan orang-orang, dan ataupun antar sesama suatu badan yang berbasis hukum.

Pada dasarya pelaku usaha sangat amat butuh dan akan bergantung pada sebagai konsumennya. Tanpa dukungannya pelaku usaha tidak akan bisa maju dan melanjutkan usahanya dalam usaha kelangsungan hidupnya. Dimana sebaliknya juga konsumen pasti sangat membutuhkan adanya suatu pelaku usaha untuk melangsungkan hidup. Hubungan konsumen dengan pihak usaha bisa di bagi jadi dua, yaitu pertama hubungan yang langsung terjadi antara konsumen dan pihak produsen yang dimana secara tidak langsung terikat dalam suatu perjanjian. Tanpa melupakan berbagai jenis perjanjian lainnya. Pada dasarnya akan dilakukan suatu perjanjian yang dilakukan secara tertulis maupun akan secara lisan. Seperti yang tertera dalam pasal 1313 KUHP berkata bahwa persetujuan maupun perjanjian dengan satu orang atau lebih mengikat diri terhadap seseorang dan atau lebih kedua hubungan yang tidak berlangsung dimana merupakan suatu hubungan antara konsumen dengan pihak produsen dengan secara tidak langsung terikat dengan adanya suatu perjanjian (Miru \& Yodo, 2008).

Perkembangan jasa dan barang industri menimbulkan dampak yang sangat dibutuhkan, sepertinya tersedianya kebutuhan yang dengan jumlah banyak. Dilain sisi terdapat juga hal yang tidak baik, dimana dengan penggunaan teknologi yang dimana pemilik usaha saling bersaing antar saru dengan pihak lain yang memiliki suatu bisnis yang hampir sama yang pasti akan mempengaruhi pihakpihak konsumen. Dengan begitu perlindungan hukum bagi konsumen dengan adanya pelanggaran data dapat dibagi menjadi sikap preventif dan juga represif, perlindungan hukum secara preventif dilakukan dengan dibuatnya klausul atau syarat ketentuan penggunaan yang dibuat sejelas-jelasnya yang disebutkan pasal 26 UU ITE, tentang perlindungan bagi pengguna jasa yang dirugikan atas kenyaman dan privasinya. Sikap represif dilakukan sesuai dengan pasal 4 UUPK dimana hak konsumen atas ketidaknyamanan yang dirasakan oleh pengguna jasa telekomunikasi dan penyelesaian sengketa dapat dilakukan diluar pengadilan.

\section{SIMPULAN DAN SARAN}

\section{Simpulan}

Berdasarkan hasil analisis data, dapat disimpulakn bahwa pengaturan hukum pengguna jasa telekomunikasi dalam bidang periklanan yaitu Permen Kominfo No.l/Per/M.Kominfo/01/2009 Tentang Penyelenggara Jasa Pesan dan Pengiriman Jasa Pesan Singkat ke banyak nomor (Broadcast), disebutkan pada Pasal 26 UU ITE untuk menjaga data pribadi pengguna jasa telekomunikasi, sehingga cara dan persepsi pengguna jasa telekomunikasi terkait promosi melalui SMS Broadcast terganggu. Perlindungan hukum kepada pengguna jasa telekomunikasi tentang pelanggaran data pribadi melalui 
SMS Broadcast 26 UU ITE, tentang perlindungan bagi pengguna jasa yang dirugikan atas kenyaman dan privasinya. Sikap represif dilakukan sesuai dengan pasal 4 UUPK dimana hak konsumen atas ketidaknyamanan yang dirasakan oleh pengguna jasa telekomunikasi dan penyelesaian sengketa dapat dilakukan diluar pengadilan.

\section{Saran}

Dari hasil penelitian di atas, adapun saran yang diberikan yaitu kepada pemerintah agar merancang kebijakan yang mengatur secara khusus berkaitan dengan perlindungan pengguna jasa telekomunikasi dari data pribadi telepon seluler sebagai payung hukum sekaligus memberikan perlindungan hukum atas hak privasi konsumen selama mengkonsumsi jasa layanan telekomunikasi dalam ruang lingkup yang lebih luas. Agar perlindungan hukum terhadap pengguna jasa telekomunikasi menjadi prioritas bagi pemerintah sehingga menjamin para konsumen unruk menggunakan telepon seluler secara aman. Diharapkan kepada pengguna telepon seluler agar lebih bijak dan lebih berhati-hati dalam menggunakan media elektronik sehingga tidak adanya data pribadi pengguna jasa telekomunikasi yang disalahgunakan dan atau digunakan untuk promosi iklan yang sangat mengganggu karena dapat mengakibatkan kerugian terhadap diri sendiri dikemudian hari.

\section{DAFTAR PUSTAKA}

Bambang, W. (2002). Penelitian Hukum dalam Praktek. Jakarta: Sinar Grafika.

Dewi, S. (2016). Konsep Perlindungan Hukum atas Privasi dan Data Pribadi Dikaitkan dengan Penggunaan Cloud Computing di Indonesia. Jurnal Hukum, 5(1).

Helmi, H. R. (2011). Perlindungan Hukum Bagi Pengguna Jasa Operator Seluler Atas Adanya Short Message Service (Sms) Spam. Yuridika, 26(3), 247-258.

Johanes, G. (1999). Tanggung Jawab Pelaku Usaha menurut Undang-undang Nomor Tahun 1999 tentang Perlindungan Hukum. Rineka Cipta.

Kristiyanti, C. T. S. (2011). Hukum Perlindungan Konsumen. Jakarta. Sinar Grafika.

Miru, A. (2011). Prinsip-prinsip-Perlindungan Hukum Bagi Konsumen di Indonesia. Depok. Raja Grafindo Persada.

Miru, A., \& Yodo, S. (2008). Hukum Perlindungan Konsumen. Depok. Raja Grafindo.

Sidabalok, J. (2006). Hukum Perlindungan Konsumen di Indonesia. Jakarta. PT Citra Adirya Bakti.

Winardi. (1992). Promosi dan Reklame. Bandung. Mandar Maju. 